\title{
A Study On Corporate Governance And Performance Effect Of Institutional Investors
}

\author{
Cheng Min \\ SHU-UTS SILC Business School, Shanghai University, \\ Shanghai, P.R.China
}

doi: 10.19044/esj.2016.v12n16p363 URL:http://dx.doi.org/10.19044/esj.2016.v12n16p363

\begin{abstract}
Recently with rapid growth of China's institutional investors, they are gradually becoming the dominant force in capital market. At the same time they start exerting influence on corporate governance and affecting corporate performance. Many previous studies have shown institutional investors' holdings are positively correlated to corporate performance. However there are still many studies holding opposite opinions. This article further studies how institutional investors influence corporate performance and whether they have effects on corporate governance. On the whole, we come to the conclusion that participation of institutional investors promotes the improvement of corporate performance. These conclusions provide theoretical and practical guidance to future development of institutional investors.
\end{abstract}

Keywords: Institutional Investors, Corporate Performance, Corporate Governance

\section{Introduction}

With the continuous development of world economy and increasing scale of capital market, market investment participants are gradually increasing and structural changes and transitions begin to occur. One of the most prominent performances is the rapid development of the institutional investors. At present, institutional investors have gradually grown into a dominant force in the developed capital market. The main purpose of developing institutional investors is to improve capital market efficiency. Many economists have proposed that the development of institutional investors contributes to appearance of bull market in the nineties, which had brought economic growth for almost ten years in the United States.

After foreign developed capital markets put forward the idea about development of institutional investors, the Chinese governments also 
encourage the development of institutional investors, and provide convenient conditions in order to give full play to their own advantages, as well as to promote stable, standardized and mature development of Chinese capital market. Since 1990s, Chinese institutional investors have been developing rapidly. These institutions also exhibit diversification patterns, such as Qualified Foreign Institutional Investors (QFII), securities investment funds, insurance companies, securities companies, social security fund and trust companies. Although there is still big gap in the extent of institutional investors' development between China and foreign developed countries, relative to individual investors, institutional investors have more professional knowledge and information advantages. The rapid rising of this investment group would exert great influence in market valuation and enterprises development.

With the rapid growing of the institutional investors, academics and regulators begin to pay close attention to market effects of institutional investors.

Compared with individual investors, institutional investors theoretically have strong capital strength, abundant information access, greater professional information analysis capability, better risk consciousness and strict risk management ability. From long-term practical operation in the capital market, institutional investors often earn a stable return. Institutional investors provide an important reference for individual investors. Hence Governments introduced a series of policies to encourage and support the development of institutional investors, aiming to use institutional investors' advantages to guide the market investment behavior, reduce the unstable factors, so as to help long-term, stable development of capital market.

Although the development course of Chinese institutional investors is short, its growth rate is amazing. Institutional investors in China have been playing played a very important role. Chinese institutional investors are actively involved in corporate governance. They constitute effective restraint to listed companies and help companies improve performance. But Chinese institutional investors are not as much mature, and need further improvement in participating in the process, ways and motivations of corporate governance. Conducting research about the impact of institutional investors' holdings on companies' performance has certain theoretical and practical significance. First, to some extent enrich and improve studies of institutional investors' role in corporate governance. And the research results can provide effective theoretical basis for relevant government bodies to guide institutional investors' development. Second, this study tries to solve Chinese long-standing corporate governance problems from the new perspective of institutional investors, and to promote the healthy and orderly 
development of the corporate governance structure, to form real corporate governance which plays an important role in enhancing economic effectiveness of the company.

Although it is well known that institutional investors make value investment based on corporate performance, whether investors can really participate in corporate governance and to improve corporate performance still need Time to test. In order to stabilize capital market, Stimulate stock market trading activity, improve corporate governance and performance of listed companies, it is necessary for Chinese regulators to further investigate investment behavior of institutional investors and their influence, and then to provide a more reasonable basis for establishment of laws and regulations system to guide institutional Investors.Enhancing more scientific investment philosophy and more rational investment behavior, motivating them to participate in corporate governance, strengthening their motivation to improve company performance so as to promote the steady development of China's securities market.As for institutional investors have investment behavior impact on corporate value, studies on institutional investors are essential and very important for the healthy development of Chinese capital market.

\section{Literature review}

Compared with social investors and individual investors, institutional investors have more professional knowledge reserves and abundant capital strength. In theory, they should more actively supervise daily operation and management activities of listed companies in order to improve the whole company performance levels. In recent years, along with the continuous theoretical development of active shareholders ideology, more and more scholars carry out the research of the influence of institutional investors on corporate performance. However, scholars have not yet agreed with the exact relationship between institutional investors' participation and corporate performance. There are still bigger divergences in relevant theoretical and empirical research conclusions for this problem. These research conclusions mainly focus on three aspects: one is that institutional investors can improve corporate performance. Secondly, institutional investors can't distinctively promote corporate performance. Third, institutional investors' holding does not have any effect on corporate performance promotion.

\section{1 literature reviews that institutional investors can improve corporate performance}

Studies that get the conclusion that institutional investors can improve corporate performance are based on an important hypothesis---effective Monitoring hypothesis. The hypothesis is first put forward by 
economic researcher Shleifer and Vishny. These two economists pointed out that in contrast with other types of shareholders, institutional investors have theoretical and professional knowledge which can greatly save cost of supervision. Along with more abundant capital, driven by benefits maximum motivation, institutional investors can earn greater returns by actively fulfilling supervision responsibilities. With this research hypothesis, Shleifer and Vishny concluded that there is significantly positive correlation between insititutional ownership and corporate performance.

With the passage of time, many western scholars' studies support the effective supervision hypothesis.Many researchers had made more in-depth studies on the corporate governance role of institutional investors (Bensten and Smith,1976; Grossman and Hart, 1980;and Gillan and Starks, 2001).They have commonly found that institutional investors holdings have positive correlation with corporate performance. That means the higher institutional investors holdings, the stronger influence on corporate performance. Institutional investors earn higher return by supervising companies, which further leads to more capabilities in monitoring daily operation and management activities of behavior. McConnell and Servaes (1990) collected 1000 listed companies as samples to study institutional investors. They use Tobin $Q$ as a representative of market value to Study future influence of institutional investors on corporate performance. Research results show that the regression coefficient of institutional investors' holdings on corporate performance is significantly positive. Thus they come to the conclusion that institutional investors effectively fulfill companies' supervision.

Chaganti (1995) used return on assets to represent the performance of listed companies and found that institutional investors' ownership and corporate performance is significantly related.

Short\&Keasey(1997) pointed out that institutional investors actively participate in companies' daily operation and management to improve longterm performance. They found institutional investors holding is significantly correlated with corporate performance. Thus institutional investors holding behavior can improve the performance of the company.

\subsection{Literature reviews institutional investors have no distinctive promotion on corporate performance}

Pound(1988) studied the relationship between institutional investor ownership and corporate performance. He put forward Interest Conflict Hypothesis and strategic alliance Hypothesis (or Negative monitoring Hypothesis). the view of interest conflict hypothesis means that institutional investors not only has its ownership in listed companies, but also may have other for-profit business transactions with these companies. That means 
Institutional investors are related parties of these companies. Therefore, they are more likely to vote for managers in violation of corporate interest. As for strategic alliance hypothesis, institutional investors and the management of listed companies form an alliance, which is profitable for both parties. This mutual cooperation can severely damage institutional investors' enthusiasm of participation in corporate governance and supervision of corporate management, which furthermore leads to the reduction of corporate value. Based on these analyses, the relationship between institutional investors and corporate performance showed significant negative correlation. Many scholars' studies also support this conclusion.

Coffee (1991) and Bamard (1992) also agreed with the inefficient supervision idea of institutional investors that is the typical representative of this hypothesis. Coffee and Banard believed that institutional investors had not played an active role in the process of improving corporate governance. They pointed out that in essence institutional investors cater for financial market to make speculative trading. Because of their negative evaluation to speculative motivation of institutional investors, the management of listed companies is not friendly, even hostile to institutional investors. Hence to a larger extent these factors hindered institutional investors to play its role in effective supervision of listed companies, which is known as internal barriers to effective monitoring. Institutional investors may be confined to its own capital market operation and is lack of related professional knowledge in other fields. Due to not enough comprehensive knowledge level, many scholars doubt institutional investors' holdings bring benefits for listed companies. Lipton and Rosenblum(1991), and Wohlstetter(1993) pointed out that although institutional investors have relative professional and information advantages, they are not enough capable of business operation and management. Lack of management technical and effective experience involved in corporate governance, they are not able to really take part in company supervision and Management decisions.

Because of focusing too much on short-term investment return, institutional investors ultimately damage long-term goal of listed companies. Romano devoted to collecting related literature about corporate governance effect of institutional investors. He eventually found that many scholars theoretically hold positive evaluation to institutional investors. But practically and empirically their research conclusions stand on the opposite. Most scholars suggest active influence of institutional investors on corporate performance is very small; some even will be up against. 


\subsection{Literature review that institutional investors have no effect on corporate performance}

Ineffective supervision hypothesis shows that institutional investors have no significant positive or negative influence on corporate governance and corporate performance. In other words institutional investors' holdings cannot exert any effect on companies' daily business activities. Wahal (1996) studied corporate governance effect of pension fund. He found that pension funds did not significant influence corporate performance in the process of participating in corporate governance effect. Ring.Smith (1996) analyzed 51 listed companies with institutional investors holding for six years from 1987 to 1993. He found that institutional investors help improve corporate share price by participating in corporate governance, but they have no significant impact on corporate performance in statistics. Guercio and Hawkins (1999) came to the conclusion that institutional investors' holding does not show significantly positive or negative impact on long-term corporate returns. To sum up, institutional investors holding behavior can not affect corporate performance.

In foreign western developed countries institutional investors start early and develop faster, correspondingly related literature about the effect of institutional investors on corporate performance are relatively mature and deep in research extent. many scholars put forward some related theories and hypothesis, but there still no consensus on this issue.Because of relatively later development of Chinese domestic institutions investors, related studies must be characteristic of Chinese practical conditions.

Chinese Domestic scholars have been studying institutional investors for some time and have achieved some instructive results. But these studies still need further improvement in research methods and research depth and profundity as well. Most Chinese domestic scholars study the effect of institutional investors holding on the performance of listed companies. But there exists some problems in research methods such as selection of variables and the treatment of endogenous issues. The mechanisms how the intervention of institutional investors affects corporate performance still need theoretical and empirical explanations. This study tries to overcome these research flaws from two aspects. The first is to introduce tools of variables to solve endogenous problems. The second is trying to explain corporate performance effects of institutional investors from corporate governance perspective.

\section{Research Hypothesis}

The influence of institutional investors on corporate performance is mainly embodied in the process of participation in internal corporate governance as well as through external flow mechanism in the equity market. 
From the point of view of internal corporate governance structure, institutional investors as an important member of the shareholders participate in corporate governance in three ways such as the general meeting of shareholders, the board of directors and board of supervisors. On the general meeting of shareholders, institutional investors' agents attend the general meeting of shareholders comment on and give advice for the operation and management decision-making of listed companies. Usually this situation through shareholders' meeting is suitable for larger institutional investors' holdings.

Institutional investors can also exert their influence by the board of directors. Institutional investors can act as members of board of directors of listed companies. Their agents as directors often participate in business operation, financial, personnel and strategic management decisions of listed companies. At the same time, these directors as corporate insiders monitor daily behavior of corporate management, which greatly improves supervision efficiency and reduces agency costs arising from information asymmetry between principal and management. In addition, with the supervision mechanism of the board of directors, institutional investors can effectively curb collusion behaviors between large shareholders, and between large shareholders and corporate managers, and effectively protect interests of minority shareholders as well. Similarly, institutional investors can take advantage of the board of supervisors to supervise corporate governance structure and improve corporate governance quality.

Institutional investors affect corporate performance goals by participating in corporate external governance are mainly involved in market mechanism of equity flows. The main ways are embodied in the securities market pricing mechanism and control rights contests. As for securities market pricing mechanism, institutional investors "vote by feet" through observing and forecasting shares' prices of listed companies. That means they purchase and sell shares, change corporate management and attract new investors based on their own profit maximization principle. These market behaviors of institutional investors to a certain extent threaten interests of management, which would force them conscientiously work hard to improve corporate performance and keep securities market prices stable. Given that institutional investors can influence corporate performance through internal and external dual mechanisms, we believe that in order to obtain higher returns and protect their own interests, institutional investors will improve corporate performance by participating corporate governance.

In China the phenomenon that majority shareholders dominate listed companies is widespread. Under this condition, institutional investors are difficult to contend against controlling shareholders. They often passively participate in corporate governance resulting in weak supervision. But there 
are still many studies showing that Chinese institutional investors have participated in the corporate governance and played an important role in the supervision of the companies' business operations. Relying on their equity held, institutional investors can change equity structure of listed companies, and monitor majority shareholders and corporate management. They can also improve corporate internal governance mechanisms such as hiring outside independent directors to change the structure and governance efficiency of the board of directors. Therefore, this paper argues that to some extent Chinese institutional investors participate in corporate governance. The higher their stakes in listed companies, the greater they will help to improve corporate performance. Therefore, we put forward the research hypothesis 1.

Hypothesis 1: as institutional investors' holdings increase, the company will have better performance.

With highly concentrated ownership structure of Chinese listed companies, majority shareholders often take a series of moves to damage the interests of minority shareholders. Institutional investors' participation in corporate governance can avoid free-riding behavior of minority shareholders. Institutional investors not only play the role of supervision, but also possibly cooperate with large shareholders to improve corporate governance. Through participating in corporate daily management and improving corporate governance, institutional investors curb "interest tunneling effect" of large shareholders to protect the interests of small and medium-sized shareholders. As a result, relative to the large shareholders, the higher institutional investors' holding, their voting in the general shareholder meeting is more influential. Of course, this kind of influence is also relative to the big shareholders. Based on relative restrictedness strength of institutional investors, we believe that institutional investors could improve corporate governance and promote corporate performance. Therefore we put forward

Hypothesis 2: the higher the counterbalance between the largest shareholder and institutional investors, the company would perform better.

After years of reform, most Chinese state-owned enterprises have established modern enterprise system. But to some extent the government still intervenes in corporate management and decisions. In present Chinese political, economic and social structures, the government remains in the leadership and strong position. In order to realize multiple development goals of government, the production and business operation of state holding companies often deviate from the interests of other small and medium shareholders. The combination between state shareholder holding position and strong governance strength makes it difficult to implement all kinds of corporate governance mechanisms. Correspondingly it also increase the cost 
and difficulty of institutional investors participating in corporate governance. Hence state controlling inhibits corporate governance effect of institutional investors. Relative to state owned companies, in non-state-owned companies' institutional investors can be better qualified for the role of supervisors and can more effectively improve the level of corporate governance and corporate performance. Therefore, we put forward research hypothesis 3.

Hypothesis 3: relative to state-owned listed companies, in nonstate-owned companies institutional investors can more significantly influence corporate performance.

\section{Research Design}

\subsection{Data source and sample selection}

In this article, all samples are selected from Chinese CSMAR database. We choose companies listed in Chinese main market from 2012 to 2014 and perform the following sample selecting processes: (1)to exclude companies without institutional participation;(2) to exclude companies with debt ratio greater than 1 ; (3) to eliminate companies in the financial industry; (4) to eliminate the industry with sample size less than 10. (5) To delete data sample with lack of variable value and incurrence of abnormal value.With the above selecting standard, we get total 5941 sample companies distributed in 10 industries during 3 years from 2012 to 2014.

\subsection{Variables definition Dependent variables}

Corporate performance evaluation method is appropriate evaluation and judgment of companies' operating results, financial position and economic performance considering various factors affecting corporate performance. From the point of view of the existing literature, corporate performance evaluation methods mainly include: Dupont analytical method, proportional method, the economic Value added (EVA), the balanced scorecard method and Tobin Q value method. In this article, we use Tobin Q value and some main financial indicators to comprehensively evaluate corporate performance. Some scholars adopt a variety of financial indicators to systematically evaluate corporate performance, such as return on equity (ROE), return on total assets (ROA), profitability from main business operation, total asset growth rate. But because these financial indicators reflect on company historical performance effect, to some extent they are unreasonable to evaluate corporate performance.

In this paper, performance indicators selection adheres to common theoretical points and use comprehensive performance measures such as Tobin Q value, earnings per share (EPS) and return on equity (ROE). The 
reasons for selecting above three indicators to reflect corporate performance are as follows. (1) Earnings per share (EPS) is the most explicit indicator reflecting profitability. It indicates what common shareholders can get from corporate earnings. EPS provides significant ground for dividend distribution. EPS indicator eliminates the factor influence of corporate size and provides an important basis for shareholders' investment decisions. (2) Return on equity (ROE) is a comprehensive and strong representative financial indicator. It is also one of the core components of enterprise performance evaluation. It can not only reflect the enterprise Profitability, but also is an integrated embodiment of business capital operation, sales scale, cost control, and financing structure etc. Since ROE shows the final result of business activities and capital investment profitability, we select it as a corporate performance evaluation indicator. (3) Tobin Q is the ratio of company's market value to total asset replacement cost. It reflects the extent to which the company is recognized by capital market, and how it is valued by market evaluation. Based on this computation that Tobin Q equals the company's market value divided by its asset replacement cost, theoretically it is difficult to manipulate Tobin Q value. Hence we also use it to measure corporate performance.

\section{Independent variables}

This paper selected three main independent variables to examine the role of institutional investors.

INS represents the proportion of institutional investors' holding in listed companies. The higher the institutional investor's stake, their motivation to participate in corporate governance is greater .And correspondingly they will exert greater influence on companies' performance. In this study we compute the total holdings of institutional investors among top ten shareholders. INT indicates the counterbalance between the largest shareholder and institutional investors. It is institutional investors' holdings divided by the largest shareholder' holding. The higher this proportion, institutional investors are more capable of counterbalancing authorities of the largest shareholders. At the same time, we expect that institutional investors are more involved in corporate governance and positively affect firm performance.

TYPE represents the ownership nature of controlling shareholders. TYPE is 1 for state holdings. Otherwise, it is zero. The nature of the controlling shareholder indicates whether the listed company is a stateowned or non-state-owned holding. Usually as a result of state holding, stateowned listed companies need to meet some requirements of the government. Because of government intervention and actual owners' absence in stateowned enterprises, it is difficult for institutional investors to participate in 
enterprise' management decision. Therefore, the role of institutional investors in non-state enterprises is relatively greater important than in stateowned enterprises.so performance effect of institutional investors in these two types of companies will show the differences.

\section{Control variable}

In order to accurately assess the role of institutional investors in corporate performance, we must strictly control other common variables that influence company performance. This study mainly considers the influence of the following control variables.

(1) LEV represents corporate solvency risk for the company. We use debt ratio to measure financial leverage risks. Generally speaking, when debt ratio is relatively lower, corporate value will increase with the rising of leverage ratio. Because of tax shield effects of debt interest expenses, the enterprise intends to use debt financing to improve shareholder returns. But if the debt ratio is too high, the company will face greater financial risk, which is harmful to business expansion and innovation

(2) GROWTH represents growth rate of main business operating revenue. It indicates corporate growth abilities. We use operating income changes (ending operating revenue minus beginning operating revenue)divided by beginning operating revenue to measure growth abilities. Due to corporate performance continuity, companies with higher growth rates tend to perform relatively well.

(3) SIZE represents corporate scale, which is measured by computing the natural logarithm of total assets. The greater the enterprise scale, the stronger the ability to resist risks. Correspondingly we expect higher operating stability for this company.

However, companies with larger scale may have complex business types, staff size and organization structure. Additionally with less flexible internal management mechanics, all these may have negative influence on governance efficiency of enterprises. As a result, it is difficult to determine the impact of corporate scale on corporate governance. In order to improve model accuracy and eliminate abnormal factors, this study also introduces a series of additional dummy variables, including auditing opinion, stock types, area development, industry, year, etc. Table 1 exhibits the definition of various variables.

Table 1 Variables definitions

\begin{tabular}{|l|l|l|}
\hline & Variables & Definitions \\
\hline \multirow{2}{*}{$\begin{array}{l}\text { Dependent } \\
\text { variables }\end{array}$} & EPS & Net profit divided by common shares issued \\
\cline { 2 - 3 } & Tobin Q & $\begin{array}{l}\text { Corporate market value divided by asset replacement } \\
\text { costs. }\end{array}$ \\
\cline { 2 - 3 } & ROE & Net profit divided by average shareholders' equity \\
\hline $\begin{array}{l}\text { Independent } \\
\text { variables }\end{array}$ & INS & $\begin{array}{l}\text { The sum of institutional investors' holdings among the } \\
\text { top ten shareholders }\end{array}$ \\
\hline
\end{tabular}




\begin{tabular}{|l|l|l|}
\hline \multirow{4}{*}{$\begin{array}{l}\text { Control } \\
\text { variables }\end{array}$} & CB & $\begin{array}{l}\text { The sum of institutional investors' holdings divided by } \\
\text { the largest shareholders' holding }\end{array}$ \\
\cline { 2 - 3 } & STATE & Dummy variable. 1 for state controlling, otherwise 0. \\
\cline { 2 - 3 } & SERF & Herfindahl Index to reflect ownership concentration. \\
\cline { 2 - 3 } & LEV & Natural logarithm of total assets \\
\cline { 2 - 3 } & GROWTH & $\begin{array}{l}\text { Debt ratio. Total liability divided by total asset. } \\
\text { (ending operating revenue minus beginning operating } \\
\text { revenue)/ beginning operating revenue }\end{array}$ \\
\cline { 2 - 3 } & OCCUPY & (Receivables-payables)/total asset \\
\cline { 2 - 3 } & HB & $\begin{array}{l}\text { Dummy variable. } 1 \text { for companies with B or H shares, } \\
\text { otherwise } 0 .\end{array}$ \\
\cline { 2 - 3 } & AUDIT & $\begin{array}{l}\text { Dummy variable. } 1 \text { for companies audited by big four } \\
\text { accounting firms. Otherwise 0. }\end{array}$ \\
\cline { 2 - 3 } & DEV & $\begin{array}{l}\text { Dummy variable. } 1 \text { for companies in eastern developed } \\
\text { area. Otherwise } 0 .\end{array}$ \\
\cline { 2 - 3 } & IND & Control variable for different industry. \\
\cline { 2 - 3 } & YEAR & Control variable for different year. \\
\hline
\end{tabular}

\subsection{Model specification}

When making investment decisions, institutional investors tend to focus on corporate past operating performance and financial position. Hence endogenous problems may exist in examining the relationship between independent and dependent variables. That is to say, corporate performance improvement may not arise from the entering of institutional investors holding. If corporate performance improvement is influenced by its past performance, this endogenous problem will disturb our examination of institutional investors' corporate role. This study uses two-stage least squares method to solve endogenous problem (Wooldridge, 2006). In the first stage, we regard institutional investor's holdings as dependent variable affected by corporate governance factors and past corporate performance, and use Model 1 to estimating the value of institutional investor's holdings. In the second stage, we examine hypotheses using the estimated institutional holdings as independent variable. Thus, this method effectively avoids endogenous problem. To examine Hypothesis 1, 2 and 3, we use the following Model 2,3 and 4 respectively. Dependent variable Performance represents ROE, EPS, and Tobin $\mathrm{Q}$ respectively.

$\mathrm{INS}=\alpha 0+\beta 1 \mathrm{HERF}+\beta 2 \mathrm{DEV}+\beta 3 \mathrm{HB}+\beta 4 \mathrm{OCCUPY}+\beta 5 \mathrm{SIZE}+\beta 6 \mathrm{GROWTH}+\beta 7$ AUDIT $+\beta 8$ EPS $+\beta$ SLEV $+\beta 10$ IND $+\varepsilon$ (1)

Performance $=\alpha 0+\beta 1$ INS $+\beta 2$ SIZE $+\beta 3$ GROWTH $+\beta 4$ AUDIT $+\beta 5 \mathrm{LEV}+\beta 6 \mathrm{IN}$ $\mathrm{D}+\beta 7$ Year $+\varepsilon(2)$

Performance $=\alpha 0+\beta 1 \mathrm{CB}+\beta 2 \mathrm{SIZE}+\beta 3 \mathrm{GROWTH}+\beta 4 \mathrm{AUDIT}+\beta 5 \mathrm{LEV}+\beta 6 \mathrm{IND}$ $+\beta 7$ Year $+\varepsilon$ (3)

Performance $=\alpha 0+\beta 1$ INS $+\beta 2$ INS $*$ STATE $++\beta 3$ SIZE $+\beta 4$ GROWTH $+\beta 5$ AUDI $\mathrm{T}+\beta 6 \mathrm{LEV}+\beta 7 \mathrm{IND}+\beta 8$ Year $+\varepsilon$ (4) 


\section{Descriptive statistics}

Since the development of institutional investors in China is not very long, it is necessary to investigate Institutional investors' share holdings in the listed companies and their counterweight as for as restricting to the big shareholder. Table 2 shows the summary statistics results of all variables. From the table, the average institutional investors' holding INS is as low as 9.6\%. Relatively lower institutional investors' holding means initial development stage of institutional investors and limited influence they can exert on listed companies. The average value of variable CB is 0.186. Compared with large shareholders, this also indicates low degree of counter balance from institutional investors. To restraint entrenchment of corporate management and large shareholders, institutional investors play limited role in participating in corporate governance. In current Chinese capital market, there is still a long way for institutional investors to contend with major shareholders. Table 3 shows Pearson correlation coefficient test results of all variables. From table 3, we can see variable INS and CB are positively significantly correlated with performance variables EPS, Tobin Q and ROE. Although institutional investors' holdings are relatively low compared with large shareholders, to some extent they can still exert. Form table 3, except variables INS and CB is highly correlated; the correlation coefficients between other explainable variables are not very significant. Hence multicollinearity problem of independent variables is not serious, and it will not disturb the following regression tests.

Table 2 Descriptive statistics of all variables

\begin{tabular}{llllll}
\hline & Average & Median & Max & Min & Std.Dev \\
\hline EPS & 0.348 & 0.265 & 14.58 & -3.81 & 0.564 \\
Tobin Q & 1.904 & 1.449 & 192.705 & 0.683 & 3.321 \\
ROE & 0.069 & 0.007 & 2.091 & -1.089 & 0.069 \\
INS & 0.096 & 0.044 & 0.799 & 0.000 & 0.129 \\
CB & 0.186 & 0.070 & 4.673 & 0.000 & 0.305 \\
STATE & 0.427 & 0.000 & 1 & 0.000 & 0.494 \\
HERF & 0.177 & 0.148 & 0.980 & 0.000 & 0.127 \\
SIZE & 21.888 & 21.724 & 28.482 & 16.161 & 1.316 \\
LEV & 0.454 & 0.442 & 13.397 & -0.194 & 0.389 \\
GROWTH & 0.222 & 0.110 & 36.753 & -0.999 & 4.673 \\
OCCUPY & -0.0299 & -0.006 & 0.478 & -9.984 & 0.216 \\
HB & 0.069 & 0.000 & 1 & 0.000 & 0.254 \\
AUDIT & 0.055 & 0.000 & 1 & 0.000 & 0.228 \\
DEV & 0.616 & 1 & 1 & 0.000 & 0.486 \\
\hline
\end{tabular}


Table 3 Pearson correlation coefficient test of all variables

\begin{tabular}{|c|c|c|c|c|c|c|c|c|c|c|c|c|c|c|}
\hline & $\begin{array}{l}\text { EP } \\
\text { S }\end{array}$ & $\begin{array}{l}\text { To } \\
\text { bin } \\
\text { Q } \\
\end{array}$ & $\begin{array}{l}\text { RO } \\
\text { E }\end{array}$ & INS & CB & $\begin{array}{l}\text { ST } \\
\text { AT } \\
\text { E }\end{array}$ & $\begin{array}{l}\text { HE } \\
\text { RF }\end{array}$ & $\begin{array}{l}\text { SIZ } \\
\text { E }\end{array}$ & $\begin{array}{l}\mathbf{L E} \\
\mathbf{V}\end{array}$ & $\begin{array}{l}\text { GRO } \\
\text { WTH }\end{array}$ & $\begin{array}{l}\text { OCC } \\
\text { UPY }\end{array}$ & HB & $\begin{array}{l}\text { AU } \\
\text { DI } \\
\text { T }\end{array}$ & $\begin{array}{l}\text { D } \\
\text { E } \\
\text { V } \\
\end{array}$ \\
\hline EPS & 1 & & & & & & & & & & & & & \\
\hline $\begin{array}{l}\text { Tobi } \\
\text { n Q }\end{array}$ & $\begin{array}{l}0.0 \\
92^{* *} \\
*\end{array}$ & 1 & & & & & & & & & & & & \\
\hline ROE & $\begin{array}{l}0.3 \\
61^{* *}\end{array}$ & $\begin{array}{l}- \\
0.0 \\
79^{* * *}\end{array}$ & 1 & & & & & & & & & & & \\
\hline INS & $\begin{array}{l}0.2 \\
73^{* *} \\
*\end{array}$ & $\begin{array}{l}0.0 \\
43^{* *}\end{array}$ & $\begin{array}{l}0.1 \\
68^{* *} \\
*\end{array}$ & 1 & & & & & & & & & & \\
\hline CB & $\begin{array}{l}0.2 \\
19^{* *} \\
*\end{array}$ & $\begin{array}{l}0.0 \\
45^{* *}\end{array}$ & $\begin{array}{l}0.1 \\
36^{* *} \\
*\end{array}$ & $\begin{array}{l}0.8 \\
97^{* *} \\
*\end{array}$ & 1 & & & & & & & & & \\
\hline $\begin{array}{l}\text { STA } \\
\text { TE }\end{array}$ & $\begin{array}{l}- \\
0.0 \\
12^{*}\end{array}$ & $\begin{array}{l}- \\
0.0 \\
66^{* *}\end{array}$ & $\begin{array}{l}- \\
0.0 \\
20\end{array}$ & $\begin{array}{l}0.0 \\
09\end{array}$ & $\begin{array}{l}- \\
0.06 \\
1^{* * *}\end{array}$ & 1 & & & & & & & & \\
\hline $\begin{array}{l}\text { HER } \\
\text { F }\end{array}$ & $\begin{array}{l}0.0 \\
33^{* *}\end{array}$ & $\begin{array}{l}- \\
0.0 \\
22 \\
\end{array}$ & $\begin{array}{l}0.0 \\
23\end{array}$ & $\begin{array}{l}- \\
0.0 \\
43^{* *}\end{array}$ & $\begin{array}{l}- \\
0.04 \\
4^{* *}\end{array}$ & $\begin{array}{l}0.02 \\
6^{*}\end{array}$ & 1 & & & & & & & \\
\hline SIZE & $\begin{array}{l}0.1 \\
92^{* *} \\
*\end{array}$ & $\begin{array}{l}- \\
0.2 \\
81^{* * *}\end{array}$ & $\begin{array}{l}0.1 \\
25^{* *} \\
*\end{array}$ & $\begin{array}{l}0.1 \\
67^{* *} \\
*\end{array}$ & $\begin{array}{l}0.08 \\
6^{* * * *}\end{array}$ & $\begin{array}{l}0.40 \\
0^{* * *}\end{array}$ & $\begin{array}{l}0.1 \\
01^{*}\end{array}$ & 1 & & & & & & \\
\hline LEV & $\begin{array}{l}- \\
0.1 \\
23^{* *} \\
*\end{array}$ & $\begin{array}{l}0.2 \\
59^{* * *}\end{array}$ & $\begin{array}{l}- \\
0.0 \\
72^{* *} \\
*\end{array}$ & $\begin{array}{l}- \\
0.0 \\
35^{* *} \\
*\end{array}$ & $\begin{array}{l}- \\
0.04 \\
8^{* * * *}\end{array}$ & $\begin{array}{l}0.14 \\
1^{* * * *}\end{array}$ & $\begin{array}{l}- \\
0.0 \\
24\end{array}$ & $\begin{array}{l}0.0 \\
88^{* *} \\
*^{*}\end{array}$ & 1 & & & & & \\
\hline $\begin{array}{l}\text { GRO } \\
\text { WTH }\end{array}$ & $\begin{array}{l}- \\
0.0 \\
01 \\
\end{array}$ & $\begin{array}{l}0.0 \\
03\end{array}$ & $\begin{array}{l}0.0 \\
09\end{array}$ & $\begin{array}{l}- \\
0.0 \\
05 \\
\end{array}$ & $\begin{array}{l}- \\
0.00 \\
2 \\
\end{array}$ & $\begin{array}{l}- \\
0.02 \\
6^{*} \\
\end{array}$ & $\begin{array}{l}0.0 \\
09\end{array}$ & $\begin{array}{l}- \\
0.0 \\
30^{*} \\
\end{array}$ & $\begin{array}{l}0.0 \\
17\end{array}$ & 1 & & & & \\
\hline $\begin{array}{l}\text { OCC } \\
\text { UPY }\end{array}$ & $\begin{array}{l}0.0 \\
55^{* *} \\
*\end{array}$ & $\begin{array}{l}- \\
0.4 \\
03^{* *} \\
*\end{array}$ & $\begin{array}{l}0.0 \\
43^{* * *} \\
*\end{array}$ & $\begin{array}{l}0.0 \\
41^{* * *} \\
*\end{array}$ & $\begin{array}{l}0.03 \\
3^{* * * *}\end{array}$ & $\begin{array}{l}- \\
0.01 \\
1\end{array}$ & $\begin{array}{l}0.0 \\
23\end{array}$ & $\begin{array}{l}0.1 \\
68^{* *} \\
*\end{array}$ & $\begin{array}{l}- \\
0.7 \\
48^{* *} \\
*\end{array}$ & $\begin{array}{l}- \\
0.020\end{array}$ & 1 & & & \\
\hline HB & $\begin{array}{l}0.0 \\
49^{* *} \\
*\end{array}$ & $\begin{array}{l}0.0 \\
21\end{array}$ & $\begin{array}{l}0.0 \\
01\end{array}$ & $\begin{array}{l}- \\
0.0 \\
53^{* *}\end{array}$ & $\begin{array}{l}-\overline{0.04} \\
6^{* * * *}\end{array}$ & $\begin{array}{l}0.18 \\
6^{* * * *}\end{array}$ & $\begin{array}{l}0.0 \\
44^{*} \\
*\end{array}$ & $\begin{array}{l}0.2 \\
73^{* *} \\
*\end{array}$ & $\begin{array}{l}0.0 \\
93^{* *} \\
*\end{array}$ & $\overline{-}-003$ & $\begin{array}{l}- \\
0.031\end{array}$ & 1 & & \\
\hline $\begin{array}{l}\text { AUD } \\
\text { IT }\end{array}$ & $\begin{array}{l}0.0 \\
74^{* *} \\
*\end{array}$ & $\begin{array}{l}- \\
0.0 \\
43^{* *}\end{array}$ & $\begin{array}{l}0.0 \\
26^{*}\end{array}$ & $\begin{array}{l}0.0 \\
09\end{array}$ & $\begin{array}{l}- \\
0.00 \\
9\end{array}$ & $\begin{array}{l}0.17 \\
0^{* * * *}\end{array}$ & $\begin{array}{l}0.0 \\
79^{*} \\
*\end{array}$ & $\begin{array}{l}0.3 \\
82^{* *} \\
*\end{array}$ & $\begin{array}{l}0.0 \\
39^{* * *} \\
*\end{array}$ & $\overline{-}-\overline{0} .008$ & 0.007 & $\begin{array}{l}0.4 \\
56^{* *} \\
*\end{array}$ & 1 & \\
\hline DEV & $\begin{array}{l}0.0 \\
52^{* *} \\
*\end{array}$ & $\begin{array}{l}- \\
0.0 \\
17\end{array}$ & $\begin{array}{l}0.0 \\
70^{* *} \\
*\end{array}$ & $\begin{array}{l}- \\
0.0 \\
23\end{array}$ & $\begin{array}{l}- \\
0.02 \\
0\end{array}$ & $\begin{array}{l}- \\
0.16 \\
6^{* * *}\end{array}$ & $\begin{array}{l}0.0 \\
23\end{array}$ & $\begin{array}{l}- \\
0.0 \\
10\end{array}$ & $\begin{array}{l}- \\
0.0 \\
70^{* *}\end{array}$ & 0.015 & 0.035 & $\begin{array}{l}0.0 \\
81^{* *} \\
*\end{array}$ & $\begin{array}{l}0.0 \\
74^{* *} \\
*\end{array}$ & 1 \\
\hline
\end{tabular}

significant at the $1 \%$ level ${ }^{* *}$ significant at the $5 \%$ level ${ }^{*}$ significant at the $10 \%$ level

\section{Regression results and explanations}

In model 1, INS is regarded as a dependent variable influenced by a series of tool variables. In the following regression examinations, independent variable INS is regression estimation result of the first stage by using model 1 . Through two stages least squares regression, we eliminate 
performance influences on institutional investors' decision making. After solving this endogenous problem, we get very high fitting degree of regression models. In examining hypothesis 1, the regression coefficients of institutional investors holding on corporate performance of EPS, ROE and Tobin Q were significantly correlated exhibited in table 4. This suggests that institutional investors' holding does have significant positive impact on corporate performance. Besides positive correlation between institutional investors holding and corporate performance, corporate scale variable SIZE is also significantly positively related with corporate performance EPS and ROE. However corporate scale SIZE is significantly negatively correlated with Tobin Q. It is likely that corporate performance increase is to some extent based on scale expansion. Market investors might think that some companies have the tendency of excessive expansion. Debt ratio as the representative of financial leverage is significantly negatively correlated with corporate performance ROE and EPS. It means that financial risks have negative impact on corporate performance. But debt ratio is significantly positively related with Tobin Q, and the market regards financial leverage as active signals. To sum up, the regression results support the hypothesis 1 very well.

Table 4 regression results of testing hypotheses 1

\begin{tabular}{|c|c|c|c|c|c|c|}
\hline Dependent varaibles & \multicolumn{2}{|l|}{ ROE } & \multicolumn{2}{|l|}{ EPS } & \multicolumn{2}{|l|}{ Tobin Q } \\
\hline & coefficient & T value & coefficient & T value & coefficient & T value \\
\hline Constant & $-0.283^{* * *}$ & -4.387 & $-0.103^{* * *}$ & -5.870 & $22.206^{* * *}$ & 22.840 \\
\hline INS & $0.482^{* *}$ & 2.389 & $2.067^{* * *}$ & 3.797 & $9.168^{* * *}$ & 3.132 \\
\hline SIZE & $0.679^{* *}$ & 2.218 & $0.056^{* * *}$ & 6.729 & $-0.868^{* * *}$ & -18.827 \\
\hline GROWTH & 0.001 & 1.552 & 0.001 & 0.660 & 0.001 & -0.300 \\
\hline AUDIT & $0.143^{* * *}$ & 9.550 & $0.143^{* * *}$ & 3.547 & $-2.404^{* * *}$ & -10.132 \\
\hline LEV & $-0.010^{*}$ & -1.718 & $-0.001^{* * *}$ & -8.679 & $0.024^{* * *}$ & 22.133 \\
\hline IND & \multicolumn{2}{|l|}{ Control } & \multicolumn{2}{|l|}{ Control } & \multicolumn{2}{|c|}{ Control } \\
\hline Year & \multicolumn{2}{|c|}{ Control } & \multicolumn{2}{|l|}{ Control } & \multicolumn{2}{|c|}{ Control } \\
\hline F-value & \multicolumn{2}{|l|}{55.631} & \multicolumn{2}{|l|}{71.745} & \multicolumn{2}{|l|}{10.156} \\
\hline Adj-R ${ }^{2}$ & \multicolumn{2}{|l|}{0.131} & \multicolumn{2}{|l|}{0.165} & \multicolumn{2}{|l|}{0.169} \\
\hline
\end{tabular}

significant at the $1 \%$ level ${ }^{* *}$ significant at the $5 \%$ level ${ }^{*}$ significant at the $10 \%$ level

Table 5 is the regression results of examining hypothesis 2.The degree of counter balance between institutional ownership and the big shareholder is significantly positively correlated with corporate performance indicators ROE, EPS and Tobin Q. When institutional investors take big stakes in companies compared with the first large shareholder, this higher degree of counter balance will provide more incentive for institutional investors to participate in corporate governance, and monitor corporate daily operation and management activities. This is proved by the result that with higher 
degree of counter balance, the companies perform better. Corporate scale SIZE is significantly positively related to financial performance indicators ROE and EPS. But corporate scale SIZE is significantly negatively related to Tobin Q. Market investors possibly believe that when company size is too large, corporate management level and facilities will fail to keep up with current scale and have damage to corporate value. As exhibited in table 5, the regression results support hypothesis 2 very well.

Table 5 regression results of testing hypotheses 2

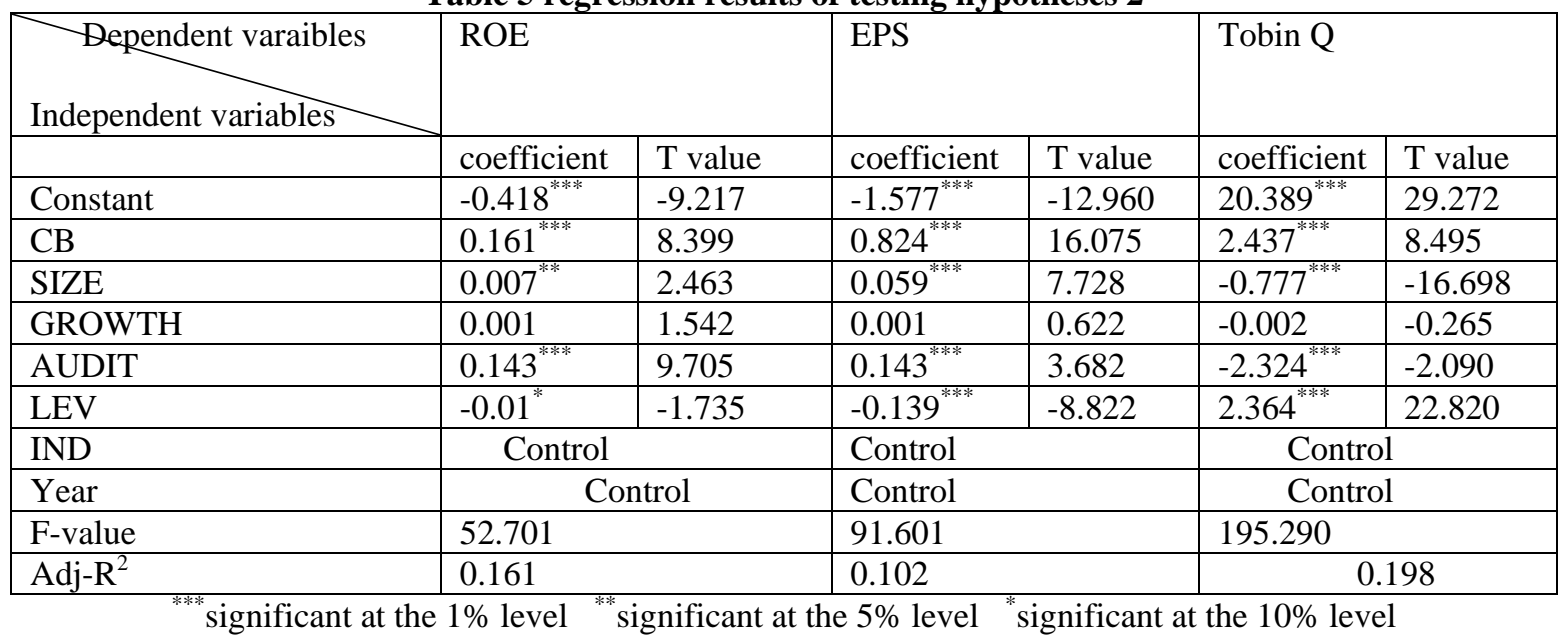

Table 6 and table 7 are the regression results of examining hypothesis 3. We build cross-term INS*STATE that is institutional investors' holding ratio multiplied by the nature of the controlling shareholders. In table 6 , the coefficients of controlling shareholder nature is significantly negatively related to financial performance indicators EPS, ROE and Tobin Q. That means corporate performance in state-owned companies is relatively low compared with non-state-owned companies. This result also explains why Chinese governments are always devoted to reforming state-owned companies. In table 7, the regression coefficients of cross-term INS*STATE are all significantly negative when dependent variables are ROE, EPS and Tobin $\mathrm{Q}$ respectively. This result indicates compared with non-state-owned companies, institutional investors play relatively weaker role in state-owned companies. Because of complex organization structures and unclear property rights, state-owned companies curb institutional investors' active participation in corporate governance. Compared with high difficulty and cost in participating state-owned corporate governance, institutional investors better play the role of supervision and corporate governance, and correspondingly have more positive impact on corporate performance in non-stated-owned companies. These results prove hypothesis 3. 
Table 6 regression results of testing hypotheses 3

\begin{tabular}{|c|c|c|c|c|c|c|}
\hline Dependent varaibles & \multicolumn{2}{|l|}{ ROE } & \multicolumn{2}{|l|}{ EPS } & \multicolumn{2}{|l|}{ Tobin Q } \\
\hline & coefficient & T value & coefficient & $\mathrm{T}$ value & coefficient & T value \\
\hline Constant & $-0.532^{* * *}$ & -11.109 & $-2.044^{* * *}$ & -15.731 & $19.980^{* * *}$ & 27.279 \\
\hline INS & $0.474^{* *}$ & 2.369 & $2.054^{* * *}$ & 3.784 & 2.265 & 0.467 \\
\hline STATE & $-0.028^{* * *}$ & -5.086 & $-0.104^{* * *}$ & -6.856 & $-0.054^{*}$ & -1.751 \\
\hline SIZE & $0.011^{* * *}$ & 3.594 & $0.007^{* * *}$ & 8.431 & $-0.780^{* * *}$ & -16.378 \\
\hline GROWTH & 0.001 & 1.455 & 0.001 & 0.507 & -0.002 & -0.250 \\
\hline AUDIT & $0.142^{* * *}$ & 9.590 & $0.142^{* * *}$ & 3.530 & $-2.319^{* * *}$ & -9.994 \\
\hline LEV & -0.008 & -1.368 & $-0.132^{* * *}$ & -8.223 & $2.337^{* * *}$ & 22.309 \\
\hline IND & \multicolumn{2}{|l|}{ Control } & \multicolumn{2}{|l|}{ Control } & \multicolumn{2}{|c|}{ Control } \\
\hline Year & \multicolumn{2}{|c|}{ Control } & \multicolumn{2}{|l|}{ Control } & \multicolumn{2}{|c|}{ Control } \\
\hline F-value & \multicolumn{2}{|c|}{46.816} & \multicolumn{2}{|l|}{63.300} & \multicolumn{2}{|c|}{184.227} \\
\hline Adj-R ${ }^{2}$ & \multicolumn{2}{|l|}{0.155} & \multicolumn{2}{|l|}{0.172} & \multicolumn{2}{|c|}{0.189} \\
\hline
\end{tabular}

Table 7 regression results of testing hypotheses 3

\begin{tabular}{|c|c|c|c|c|c|c|}
\hline Dependent varaibles & \multicolumn{2}{|l|}{$\mathrm{ROE}$} & \multicolumn{2}{|l|}{ EPS } & \multicolumn{2}{|l|}{ Tobin Q } \\
\hline & coefficient & T value & coefficient & T value & coefficient & $\mathrm{T}$ value \\
\hline Constant & $-0.545^{* * *}$ & -11.157 & $-2.081^{* * *}$ & -15.655 & $20.225^{* * *}$ & 27.101 \\
\hline INS & $0.510^{* *}$ & 2.549 & $2.184^{* * *}$ & 4.022 & 2.179 & 0.699 \\
\hline STATE & $-0.045^{* * *}$ & -4.122 & $-0.117^{* * *}$ & -6.332 & $-0.085^{* * *}$ & -3.012 \\
\hline INS*STATE & $-0.065^{* * *}$ & -5.030 & $-0.228^{* * *}$ & -6.454 & $-0.094^{* * *}$ & -3.120 \\
\hline SIZE & $0.011^{* * *}$ & 3.573 & $0.007^{* * *}$ & 8.308 & $-0.809^{* * *}$ & -16.615 \\
\hline GROWTH & 0.001 & 1.460 & 0.001 & 0.519 & -0.002 & -0.234 \\
\hline AUDIT & $0.142^{* * *}$ & 9.591 & $0.143^{* * *}$ & 3.538 & $-2.316^{* * *}$ & -9.983 \\
\hline LEV & -0.008 & -1.334 & $-0.132^{* * *}$ & -8.201 & $2.328^{* * *}$ & 22.127 \\
\hline IND & \multicolumn{2}{|l|}{ Control } & \multicolumn{2}{|l|}{ Control } & \multicolumn{2}{|c|}{ Control } \\
\hline Year & \multicolumn{2}{|c|}{ Control } & \multicolumn{2}{|l|}{ Control } & \multicolumn{2}{|c|}{ Control } \\
\hline F-value & \multicolumn{2}{|l|}{46.744} & \multicolumn{2}{|l|}{62.585} & \multicolumn{2}{|l|}{184.495} \\
\hline Adj-R ${ }^{2}$ & \multicolumn{2}{|l|}{0.155} & \multicolumn{2}{|l|}{0.102} & \multicolumn{2}{|c|}{0.190} \\
\hline
\end{tabular}

\section{Sensitivity tests}

Table 8 exhibits sensitivity tests results using ROA as dependent variable. From the table, we can see the proportion of institutional investors is significantly positively related to corporate return on asset. This means Chinese institutional investors are actively influencing corporate performance. This further proves active governance role institutional investors are playing. When we use return on asset as performance indicator, the degree of counter balance between institutional investors and the large shareholders is also positively related to ROA. This means the higher institutional investors' stake relative to the big shareholder, the more 
incentives they have to participate in corporate governance process, and prevent big shareholders from exploiting the rights and interests of minority shareholders, and correspondingly improve corporate performance. This conclusion further supports hypothesis 2 . When we use return on asset as performance indicator, the regression coefficient of cross-term INS*STATE is -0.014 , and significant at $10 \%$ statistic level. The regression coefficient of STATE is -0.012 and significant at $10 \%$ statistic level. These results show the state nature of controlling shareholders has negative impact on corporate performance. The state nature of controlling shareholders restrain institutional investors' governance role. Compared with state-owned companies, institutional investors more actively participate in corporate governance of non-state-owned companies. Therefore, relative to stateowned companies, institutional investors have much more performance effect in non-state-owned companies. All these sensitivity tests further support hypothesis 1,2 and 3.

Table 8 sensitivity tests results using ROA as dependent variable

\begin{tabular}{|c|c|c|c|c|c|c|}
\hline Hypothesis & \multicolumn{2}{|l|}{ H1 } & \multicolumn{2}{|l|}{$\mathrm{H} 2$} & \multicolumn{2}{|l|}{ H3 } \\
\hline & coefficient & T value & coefficient & T value & coefficient & T value \\
\hline Constant & -0.170 & -1.293 & $0.494^{* * *}$ & 6.932 & $0.447^{* * *}$ & 5.838 \\
\hline INS & $1.951^{* * *}$ & 4.786 & & & $-1.932^{* * *}$ & -6.166 \\
\hline CB & & & $0.126^{* * *}$ & 4.180 & & \\
\hline STATE & & & & & $-0.012^{*}$ & -1.895 \\
\hline INS*STATE & & & & & $-0.014^{*}$ & -1.898 \\
\hline SIZE & $0.019^{* * *}$ & 3.177 & $0.020^{* * *}$ & 4.251 & $0.021^{* * * *}$ & 4.172 \\
\hline GROWTH & 0.001 & 0.211 & 0.001 & 0.257 & 0.000 & 0.249 \\
\hline AUDIT & $-0.094^{* * *}$ & -3.121 & $-0.094^{* * *}$ & -4.036 & $-0.093^{* * *}$ & -4.030 \\
\hline LEV & $-0.054^{* * *}$ & -4.493 & $-0.054^{* * *}$ & -5.868 & $-0.054^{* * *}$ & -5.814 \\
\hline IND & \multicolumn{2}{|l|}{ Control } & \multicolumn{2}{|l|}{ Control } & \multicolumn{2}{|c|}{ Control } \\
\hline Year & \multicolumn{2}{|c|}{ Control } & \multicolumn{2}{|l|}{ Control } & \multicolumn{2}{|c|}{ Control } \\
\hline F-value & \multicolumn{2}{|l|}{15.52} & \multicolumn{2}{|l|}{15.463} & \multicolumn{2}{|l|}{13.307} \\
\hline Adj-R ${ }^{2}$ & \multicolumn{2}{|l|}{0.119} & \multicolumn{2}{|l|}{0.119} & \multicolumn{2}{|c|}{0.116} \\
\hline
\end{tabular}

significant at the $1 \%$ level ${ }^{* *}$ significant at the $5 \%$ level ${ }^{*}$ significant at the $10 \%$ level

\section{Conclusions}

This study tries to answer whether Chinese institutional investors exert performance and governance effect on publicly listed companies. Based on a series of descriptive statistics and regression analyses, our empirical study draws the following conclusions:

(1) Institutional investors' holding is significantly positively related to corporate performance. The empirical results show when institutional investors have higher stake in companies, they tend to engage in corporate governance and daily management to improve corporate 
performance. And correspondingly they achieve higher return on their investment.

(2) When the degree of counter balance between institutional investors and the first big shareholder is higher, the corporate perform relatively better. Compared with the majority shareholders, the greater institutional investors' stakes are in companies, the more voting rights they have in corporate governance, management and decision-making activities. Correspondingly they enhance corporate performance effect.

(3) Compared with state-owned companies, institutional investors exert greater performance influence on non-state-owned companies. Because of dominant state equity structure and strong position of governments, it is difficult for institutional investors to participate in corporate governance in state-owned companies. Hence the nature of statecontrolling inhibits corporate governance effect of institutional investors. In the non-state-owned companies, institutional investors are better qualified for the role of the supervisor. It is easier for them to monitor corporate management and participate in corporate governance. Thus institutional investors more effectively improve the level of corporate governance and corporate performance. Therefore, relative to state holding listed companies, institutional investors' holdings in non-stateowned listed companies perform better.

Empirical evidence shows that institutional investors can improve financial performance of listed companies. But on the whole, Chinese institutional investors are not enough developed such as fewer kinds of institutional investors and lack of scale advantages. Arising from weak strength of institutional investors, it is difficult for them to fully play the role of corporate governance. Therefore it is urgent to improve legal and institutional environment to promote the development of Chinese institutional investors.

\section{Reference}

Jensen.1993.The modern industrial revolution, exit, and the failure of internal control systems. Journal of Finance? 48: 831-880

Mc.Coxmell and Servaes. 1990.Additional Evidence on Equity Ownership and Corporate Value.Joumal of Financial Economies,

595-612 Bushee.2001.Do Istitutional investors Prefer Near-term Earnings over Long-run Value.Contemporary accounting Research, 18:321-335

Monks and Minow. 1995.Corporate Governance.Brasil Blackwell Inc Michae] Useem. 1996.Investor Capitalism: How Money Managers are Changing the Face of Corporate America. New York: Basic Books. 
Bushee.2001.Do Istitutional investors Prefer Near-term Earnings over Longrun Value.Contemporary accounting Research, 18:321-335

Jensen. 1993.The modern industrial revolution, exit, and the failure of internal control systems. Journal of Finance? 48: 831-880

Mc.Coxmell and Servaes. 1990.Additional Evidence on Equity Ownership and Corporate Value.Joumal of Financial Economies, 595-612

Monks and Minow. 1995.Corporate Governance.Brasil Blackwell Inc

Michae] Useem. 1996.Investor Capitalism: How Money Managers are Changing the Face of Corporate America. New York: Basic Books.

Michael P. Smith. 1996.Shareholder Activism by Institutional Investors:

Evidence from CaLPERS. Journal of Finance, 51:227-252.

Shleifer , Vishny. 1986.Large shareholders and corporate control Journal of Political Economy, 94: 461-488

Kim O. Disagreements among shareholders over a firm's disclosure policy[J].Journal of Finance, 1993(48):747-760.

Strickland. Deon, Kenneth W. Wiles, Marc Zenner.1996.A Requiemfor the USA:Is Small Shareholder Monitoring Effective. Journal of Financial Economics,40: 319-338.

BUSHEE, B.Do institutional investors prefer near-team earning over long—run value[J].Contemporary Accounting Research, 2001, 18(2):207246

Useem, M, E.Bowman, J.Myatt and Cirvine.U.S.Institutional Investors Look at Corporate Governance in the 1990's [J].European Management Journal, 1993, (11):98-131. 